\title{
Faktor-faktor yang Mempengaruhi Integrasi Pengembangan Kawasan Wisata di Pulau Segitiga Emas Kabupaten Sumenep
}

\author{
Lailatul Jum'atin Jannah dan Hertiari Idajati \\ Perencanaan Wilayah dan Kota, Fakultas Arsitektur Desain dan Perencanaan, \\ Institut Teknologi Sepuluh Nopember (ITS) \\ e-mail: hertiari_idajati@urplan.its.ac.id
}

\begin{abstract}
Abstrak-Pulau Segitiga Emas yang terdiri dari Pulau Gili Iyang, Gili Labak, dan Gili Genting terletak di Kabupaten Sumenep, Jawa Timur merupakan salah satu wisata yang mempunyai perbedaan distribusi dan trend jumlah wisatawan. Hal ini karena beberapa masalah seperti minimnya penyediaan sarana prasarana terutama di Pulau Gili Labak, akomodasi wisata yang kurang memadai di Pulau Gili Iyang, tidak adanya sarana kesehatan di destinasi wisata Pulau Gili Genting, serta tidak adanya dermaga wisata di Pulau Gili Iyang dan Gili Labak. Hal ini perlu adanya penyelesaian secara terintegrasi di tiga pulau yang disebut Pulau Segitiga Emas. Tujuan dari penelitian ini adalah untuk merumuskan strategi pengembangan kawasan wisata yang terintegrasi berdasarkan konsep integrated tourism di Pulau Segitiga Emas, Kabupaten Sumenep. Penelitian ini terdiri dari 3 tahap. Tahap pertama menggunakan Analisis Deskriptif Kualitatif untuk mengidentifikasi potensi dan kendala di masing-masing pulau. Tahap kedua menggunakan Analisis Delphi, untuk menentukan faktor-faktor yang mempengaruhi pengembangan kawasan wisata yang terintegrasi di Pulau Segitiga Emas. Tahap terakhir menggunakan Analisis Deskriptif Kualitatif untuk merumuskan strategi pengembangan kawasan wisata yang terintegrasi di Pulau Segitiga Emas, Kabupaten Sumenep. Hasil dari penelitian ini yaitu strategi pengembangan kawasan wisata, seperti membuat tema wisata di tiga pulau sesuai dengan karaktertistik, menentukan diferensiasi kegiatan, menyelaraskan penyediaan fasilitas penyebrangan, menkoordinasikan penyediaan informasi moda transportasi berdasarkan jadwal wisata, mengintegrasikan penjadwalan penyebrangan antar pulau melalui paket wisata, dan melakukan sinergi publikasi wisata Pulau Segitiga Emas.
\end{abstract}

Kata Kunci-Pulau Segitiga Emas, Integrasi Wisata, Analisis Delphi.

\section{PENDAHULUAN}

$\mathrm{P}$ ULAU Segitiga Emas merupakan sebuah julukan dari tiga pulau yaitu Pulau Gili Iyang, Gili Labak, dan Pulau Gili Genting yang terletak di Kabupaten Sumenep, Jawa Timur. Julukan ini sebagai bentuk upaya branding wisata di Kabupaten Sumenep untuk mendukung program Visit Sumenep 2018. Dimana program tersebut menargetkan dapat menarik 1 juta wisatawan berkunjung ke Kabupaten Sumenep pada tahun 2018.

Dengan adanya tagline Pulau Segitiga Emas berarti Pemerintah Daerah ingin mengembangkan kegiatan pariwisata secara terintegrasi di tiga pulau yang terdiri dari Pulau Gili Iyang, Gili Labak, dan Pulau Gili Genting. Tiga pulau ini memiliki lokasi yang saling berdekatan dan apabila dihubungkan akan membentuk garis segitiga. Tiga pulau ini juga memiliki potensi dan daya tarik wisata yang berbedabeda pada masing-masing pulau.
Dimana Pulau Gili Iyang memiliki daya tarik wisata kesehatan dengan kandungan oksigen (O2) terbaik di dunia sebesar $21 \%$ di atas rata-rata berdasarkan penelitian LAPAN (Lembaga Penerbangan dan Antariksa Nasional) dan Penelitian BLH Kabupaten Sumenep Tahun 2016. Pulau Gili Labak merupakan wisata bahari yang dikenal dengan perairannya yang jernih berisi biota laut dan terumbu karang. Sedangkan, Pulau Gili Genting terkenal dengan alam yang menawarkan panorama dan keunikan pantai menyerupai angka 9.

Berdasarkan data pengunjung Dinas Pariwisata, Kebudayaan, Pemuda dan Olahraga (Disparbudpora) Kabupaten Sumenep, jumlah wisatawan meningkat sebesar 65\%. Dimana, pada tahun 2016 sebanyak 21.030 orang, meningkat menjadi 61.174 orang pada tahun 2017. Apabila, dilihat rincian jumlah pengunjung tahun 2017, Pulau Gili Iyang dengan luas pulau sebesar $9 \mathrm{~km} 2$ ini memiliki sebanyak 7.754 wisatawan, Pulau Gili Labak yang merupakan pulau terkecil dengan luas wilayah hanya $5 \mathrm{Ha}$ ini memiliki sebanyak 31.089 wisatawan, sedangkan Pulau Gili Genting dengan luas pulau sebesar 30,3 km2 ini memiliki sebanyak 75.775 wisatawan. Apabila dilihat dari trend jumlah wisatawan di tiga pulau tersebut dari tahun 2016-2017 terjadi ketidak seimbangan, dimana jumlah kunjungan wisatawan Pulau Gili Iyang meningkat sebesar 20\%, Pulau Gili Labak mengalami penurunan sebesar 8\%, sedangkan Pulau Gili Genting merupakan destinasi wisata baru di Kabupaten Sumenep.

Selain persoalan perbedaan distribusi dan trend jumlah wisatawan di tiga pulau tersebut, masalah lain yang ada yaitu minimnya penyediaan sarana dan prasarana di Pulau Gili Labak terutama ketersediaan listrik dan air bersih, masalah akomodasi wisata yang kurang memadai di Pulau Gili Iyang, sarana kesehatan yang tidak ada di destinasi wisata Pulau Gili Genting, dan aksessibilitas yang memprihatinkan di Pulau Gili Iyang, serta tidak adanya dermaga wisata di Pulau Gili Iyang dan Gili Labak[1].

Dengan adanya potensi dan masalah di atas, maka perlu dilakukan identifikasi faktor-faktor yang mempengaruhi integrasi pengembangan wisata di Pulau Segitiga Emas, Kabupaten Sumenep.

\section{METODE PENELITIAN}

\section{A. Pendekatan Penelitian}

Pendekatan yang digunakan pada penelitian ini adalah pendekatan rasionalistik. Metode rasionalistik merupakan metode dengan peneliti bertindak sebagai instrumen utama, penelitian dilakukan dengan proses interview secara mendalam dan mendetail secara silang dan berulang untuk 
dapat mengetahui perkembangan kawasan, lingkungan serta perubahan-perubahan yang mungkin terjadi. Pendekatan rasionalistik adalah pendekatan yang bersumber dari teori dan kondisi empiris serta memperlihatkan nilai-nilai yang ada di masyarakat[2].

\section{B. Jenis Penelitian}

Dalam penelitian ini digunakan jenis pendekatan penelitian deskriptif kualitatif. Penelitian deskriptif kualitatif merupakan suatu penelitian yang dilakukan dengan tujuan utama untuk memberikan gambaran atau deskripsi tentang keadaan suatu obyek. Landasan teori dimanfaatkan sebagai pemandu atau pedoman agar fokus penelitian sesuai dengan fakta di lapangan[3].

\section{Variabel Penelitian}

Variabel penelitian adalah suatu kumpulan atribut atau sifat atau nilai dari suatu obyek atau kegiatan yang ditetapkan oleh peneliti untuk dideskripsikan dan kemudian ditarik kesimpulannya. Variabel penelitian diperoleh berdasarkan kajian pustaka dan kemudian dipilih berdasarkan kesesuaiannya dengan kebutuhan penelitian. Variabelvariabel yang digunakan seperti yang terdapat pada Tabel 1 .

Tabel 1.

Variabel Penelitian

\begin{tabular}{|c|c|c|}
\hline Indikator & Variabel & Sub-Variabel \\
\hline \multirow[t]{3}{*}{$\begin{array}{l}\text { Daya Tarik } \\
\text { Wisata }\end{array}$} & $\begin{array}{l}\text { Kedekatan geografis } \\
\text { DTW }\end{array}$ & - \\
\hline & $\begin{array}{l}\text { Diferensiasi atraksi } \\
\text { wisata }\end{array}$ & $\begin{array}{l}\text { 1. Diferensiasi atraksi } \\
\text { wisata alami }\end{array}$ \\
\hline & & $\begin{array}{l}\text { 2. Diferensiasi event yang } \\
\text { diadakan di ODTW }\end{array}$ \\
\hline \multirow[t]{9}{*}{ Aksessibilitas } & $\begin{array}{l}\text { Moda transportasi } \\
\text { penghubung }\end{array}$ & $\begin{array}{l}\text { 3. Jenis fasilitas } \\
\text { penyebrangan }\end{array}$ \\
\hline & & 4. Jadwal penyebrangan \\
\hline & & $\begin{array}{l}\text { 5. Kualitas moda } \\
\text { transportasi penyebrangan }\end{array}$ \\
\hline & $\begin{array}{l}\text { Keterjangkauan } \\
\text { moda transportasi } \\
\text { penghubung }\end{array}$ & $\begin{array}{l}\text { 6. Kemudahan } \\
\text { memperoleh moda } \\
\text { transportasi penyebrangan }\end{array}$ \\
\hline & & $\begin{array}{l}\text { 7. Kemudahan } \\
\text { mendapatkan informasi } \\
\text { jadwal penyebrangan }\end{array}$ \\
\hline & & $\begin{array}{l}\text { 8. Biaya moda transportasi } \\
\text { penyebrangan }\end{array}$ \\
\hline & $\begin{array}{l}\text { Ketersediaan akses } \\
\text { pengubung destinasi }\end{array}$ & $\begin{array}{l}\text { 9. Ketersediaan rute } \\
\text { penyebrangan }\end{array}$ \\
\hline & & $\begin{array}{l}\text { 10.Perbedaan rute } \\
\text { keberangkatan dan } \\
\text { kepulangan }\end{array}$ \\
\hline & & $\begin{array}{l}\text { 11.Rute alternatif } \\
\text { penyebrangan }\end{array}$ \\
\hline \multirow[t]{3}{*}{$\begin{array}{l}\text { Fasilitas } \\
\text { Pendukung }\end{array}$} & $\begin{array}{l}\text { Ketersediaan } \\
\text { fasilitas pendukung }\end{array}$ & $\begin{array}{l}\text { 12.Ketersediaan kelompok } \\
\text { penyedia jasa } \\
\text { penyebrangan }\end{array}$ \\
\hline & & $\begin{array}{l}\text { 13.Ketersediaan kantor } \\
\text { informasi wisata }\end{array}$ \\
\hline & $\begin{array}{l}\text { Keterpaduan fasilitas } \\
\text { pendukung }\end{array}$ & $\begin{array}{l}\text { 14.Keterpaduan fasilitas } \\
\text { penginapan }\end{array}$ \\
\hline
\end{tabular}

15.Keterpaduan fasilitas tempat makan

16.Keterpaduan antar kondisi infrastruktur

$\begin{array}{lll}\text { Kelembagaan } & \begin{array}{l}\text { Kebijakan } \\ \text { pemerintah }\end{array} & \begin{array}{l}\text { 17.Peran pemerintah dalam } \\ \text { pengembangan kawasan } \\ \text { wisata }\end{array} \\ & \begin{array}{l}\text { 18.Upaya pemerintah } \\ \text { dalam pengembangan } \\ \text { kawasan wisata }\end{array} \\ & \begin{array}{l}\text { 19.Keterlibatan masyarakat } \\ \text { Keterlibatan } \\ \text { masyarakat lokal }\end{array} & \begin{array}{l}\text { 20.Keterlibatan masyarakat } \\ \text { dalam pemasaran }\end{array} \\ & \\ & \begin{array}{l}\text { Kerjasama antara } \\ \text { pemerintah, } \\ \text { pengelola, investor } \\ \text { dan masyarakat }\end{array} & \\ & \\ \text { Kerja sama antara } & \\ \text { pengelola dan agen } & \\ \text { travel } & \\ & \\ \text { Kebijakan dan upaya } & \text { 21.Publikasi destinasi } \\ \text { promosi destinasi } & \text { wisata } \\ \text { wisata } & \text { 22.Pemasaran destinasi } \\ \text { Promosi } & \text { wisata }\end{array}$

\section{Populasi dan Sampel}

Dalam menentukan faktor - faktor yang mempengaruhi pengembangan kawasan wisata yang terintegrasi di Pulau Segitiga Emas Kabupaten Sumenep, maka diperlukan stakeholder yang mengerti tentang pengembangan kawasan wisata Pulau Segitiga Emas itu sendiri. Kemudian setelah dilakukan analisis stakeholder berdasarkan tingkat kepentingan dan pengaruh pada masing - masing stakeholder maka diketahui bahwa sampel dalam penelitian terdiri dari pemerintah, swasta dan masyarakat. Dimana pemerintah antara lain seperti Bappeda Sumenep, Disbudparpora Kabupaten Sumenep, Dinas PRKP dan Cipta Karya Sumenep, Kantor Kecamatan, dan Kepala Desa. Untuk pihak swasta seperti pengelola wisata, agent travel, pihak penyedia penginapan dan tempat makanan (restoran). Sedangkan, masyarakat sendiri yaitu masyarakat lokal dan Pokdarwis. Pada penelitian ini, setelah dilakukan screening terhadap responden penelitian atau stakeholder maka terdapat 6 stakeholder terpilih yang dijadikan sebagai responden penelitian, diantaranya Disbudparpora Kabupaten Sumenep (Responden 1), Dinas Cipta Karya Kabupaten Sumenep (Responden 2), POKDARIWS Andang Taruna Pulau Gili Iyang (Responden 3), Agent Travel Laut Biru Express (Responden 4), Pengelola Wisata Pantai Sembilan Pulau Gili Genting (Responden 5), dan POKDARWIS Pulau Gili Labak (Responden 6).

\section{E. Metode Pengumpulan Data}

Teknik pengumpulan data yang digunakan dalam penelitian ini yaitu dilakukan dengan survey primer dengan cara mengisi kuisioner penelitian melalui wawancara atau indept interview kepada stakeholder yang telah ditentukan.

\section{F. Metode Analisis Data}

Analisis yang digunakan untuk mengidentifikasi faktorfaktor yang mempengaruhi integrasi pengembangan kawasan wisata Pulau Segitiga Emas Kabupaten Sumenep sesuai 
dengan variabel yang telah ditentukan dalam penelitian yaitu Analisis Delphi. Analisis Dephi merupakan metode penelitian kualitatif yang digunakan untuk untuk membahas suatu permasalahan dengan tujuan mencapai konsensus atau kesepakatan[4]. Analisis Delphi dilakukan dengan cara menyebar kuisioner dan melakukan wawancara semi terstruktur kepada responden yang terpilih pada analisis stakeholder. Kuisioner analisis delphi yang disebarkan dilakukan secara bertahap tergantung ketercapaian konsensus atau kesepakatan responden. Apabila terdapat responden yang belum menyetujui variabel dalam faktor-faktor yang mempengaruhi integrasi pengembangan kawasan wisata Pulau Segitiga Emas Kabupaten Sumenep ini, maka dilanjutkan kepada tahap II dimana dilakukan iterasi (pengulangan) kepada responden tersebut sampai terjadi konsensus antar responden. Berikut ini merupakan langkahlangkah dari tahap analisi delphi dalam penelitian ini:

\section{Wawancara Stakeholder}

Stakeholder yang dimaksud adalah stakeholder yang telah ditentukan dalam sampel penelitian. Wawancara yang dilakukan untuk mengetahui apakah variabel yang telah dirumuskan dari hasil sintesa teori dapat dijadikan sebagai faktor-faktor yang mempengaruhi integrasi pengembangan kawasan wisata di Pulau Segitiga Emas Kabupaten Sumenep.

\section{Reduksi dan Tampilan Data Hasil Wawancara}

Reduksi data yang dimaksud di sini adalah proses memilih dan memfokuskan data dari transkip hasil wawancara eksplorasi dengan stakeholder. Dari ringkasan hasil wawancara dan proses reduksi maka didapatkan faktor-faktor yang berpengaruh terhadap integrasi pengembangan kawasan wisata Pulau Segitiga Emas Kabupaten Sumenep berdasarkan pendapat dari para stakeholder terpilih (key responden).

\section{Iterasi dan Penarikan Kesimpulan}

Iterasi atau pengulangan di sini ditujukan untuk memastikan apakah instrumen hasil wawancara sesuai dengan maksud yang diberikan oleh masing-masing stakeholder. Dari hasil identifikasi instrumen berdasarkan pendapat dari masing-masing responden, kemudian dikelompokkan secara substansial. Terhadap instrumen lain yang belum disebutkan oleh semua stakeholder, maka akan dilakukan cross check terhadap responden lainnya. Sehingga dapat dirumuskan kesimpulan faktor-faktor yang mempengaruhi pengembangan kawasan wisata yang terintegrasi di Pulau Segitiga Emas Kabupaten Sumenep.

\section{HASIL DAN PEMBAHASAN}

Berdasarkan hasil wawancara melalui penyebaran kuisioner penelitian kepada stakeholder terpilih, faktor-faktor yang mempengaruhi integrasi pengembangan kawasan wisata di Pulau Segitiga Emas yaitu sebagai berikut:

\section{A. Eksplorasi Analisis Delphi Tahap I}

Pada analisis delphi tahap I metode yang digunakan yaitu wawancara semi terstruktur, dimana responden secara langsung menyatakan pendapat menurut pengalaman dan wawasannya terkait faktor-faktor yang mempengaruhi integrasi pengembangan kawasan wisata di Pulau Segitiga Emas Kabupaten Sumenep, serta boleh dilakukan penambahan variabel oleh responden selama variabelnya masih dapat diterima dan berhubungan dengan faktor-faktor yang mempengaruhi integrasi pengembangan kawasam wisata di Pulau Segitiga Emas Kabupaten Sumenep.
Hasil wawancara tahap I yaitu eksplorasi komponen secara signifikan mempengaruhi integrasi pengembangan kawasan wisata di Pulau Segitiga Emas Kabupaten Sumenep berdasarkan pendapat responden.

Tabel 1.

Hasil Eksplorasi Analisis Delphi Tahap I

\begin{tabular}{|c|c|c|}
\hline $\begin{array}{l}\text { Hasil Analisis } \\
\text { (Konsensus } \\
\text { Responden) }\end{array}$ & $\begin{array}{l}\sum \text { (Jumlah } \\
\text { Variabel) }\end{array}$ & Variabel \\
\hline $100 \%$ & 19 & $\begin{array}{l}\text { diferensiasi atraksi wisata alami, } \\
\text { diferensiasi event di ODTW; jenis } \\
\text { fasilitas penyebrangan; jadwal } \\
\text { penyebrangan; kualitas moda } \\
\text { transportasi } \\
\text { kemudahan memperoleh moda } \\
\text { transportasi penyebrangan; } \\
\text { kemudahan mendapatkan informasi } \\
\text { jadwal penyebrangan; biaya moda } \\
\text { transportasi penyebrangan; } \\
\text { ketersediaan rute penyebrangan; } \\
\text { keterpaduan fasilitas penginapan; } \\
\text { keterpaduan fasilitas tempat makan; } \\
\text { keterpaduan infrastruktur; peran } \\
\text { pemerintah dalam pengembangan } \\
\text { wisata; upaya pemerintah dalam } \\
\text { pengemmbangan wisata, keterlibatan } \\
\text { masyarakat dalam pengelolaan; } \\
\text { keterlibatan masyarakat dalam } \\
\text { pemasaran; kerjasama antara } \\
\text { pemerintah, investor,dan masyarakat } \\
\text { lokal;publikasi destinasi } \\
\text { wisata;pemasaran destinasi wisata }\end{array}$ \\
\hline $83 \%$ & 3 & $\begin{array}{l}\text { kedekatan antar } \begin{array}{r}\text { destinasi } \\
\text { wisata;ketersediaan }\end{array} \text { kelompok } \\
\text { penyedia jasa penyebrangan; } \\
\text { kerjasama antara pengelola dan agent } \\
\text { travel }\end{array}$ \\
\hline $67 \%$ & 2 & $\begin{array}{lr}\text { Perbedaan rute } & \text { kebrangkatan dan } \\
\text { kepulangan;rute } & \text { alternatif } \\
\text { penyebrangan } & \end{array}$ \\
\hline $33 \%$ & 1 & $\begin{array}{l}\text { kantor informasi wisata di kawasan } \\
\text { wisata }\end{array}$ \\
\hline
\end{tabular}

Total Variabel 25

Berdasarkan Tabel 2 dapat diketahui bahwa terdapat 19 variabel yang $100 \%$ responden sepakat dapat mempengaruhi integrasi pengembangan kawasan wisata di Pulau Segitiga emas, Kabupaten Sumenep. Sebanyak 3 variabel yang 83\% responden sepakat mempengaruhi integrasi pengembangan kawasan wisata di Pulau Segitiga Emas, dan sebanyak 2 variabel yang $67 \%$ responden sepakat mempengaruhi integrasi pengembangan kawasan wisata di Pulau Segitiga Emas, serta 1 variabel yang 33\% responden sepakat mempengaruhi integrasi pengembangan kawasan wisata di Pulau Segitiga Emas Kabupaten Sumenep.

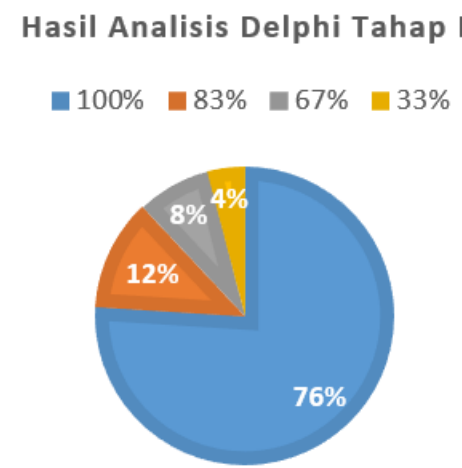

Gambar 1. Diagram hasil analisis delphi tahap I. 
Berdasarkan Gambar 1 analisis dephi tahap I sebesar 76\% responden setuju $100 \%$ terhadap variabel yang mempengaruhi integrasi pengembangan kawasan wisata di Pulau Segitiga Emas Kabupaten Sumenep. Terdapat 19 variabel disepakati oleh responden sebagai faktor-faktor yang mempengaruhi integrasi pengembangan kawasan wisata di Pulau Segitiga Emas Kabupaten Sumenep. Dari jumlah total 25 variabel terdapat 6 variabel yang belum disepakati 100\% oleh responden. Enam variabel atau faktor yang belum mencapai konsensus diantaranya, yaitu kedekatan antar destinasi wisata, perbedaan rute keberangkatan dan kepulangan, rute alternatif penyebrangan, ketersediaan kelompok penyedia jasa penyebrangan, ketersediaan kantor informasi wisata di kawasan wisata, serta kerja sama antara pengelola dan agen travel.

Kemudian pada Analisis Delphi tahap I, terdapat penambahan faktor oleh responden yang dijadikan sebagai varaibel baru. Dimana ada 3 varaibel baru berdasarkan hasil wawancara Analisis Delphi Tahap I dengan responden diantaranya, yaitu:

1. Modal sosial masyarakat (sikap masyarakat ; keramahan) di kawasan wisata Pulau Segitaga Emas Kabupaten Sumenep.

2. Tersedianya signal internet di kawasan wisata Pulau Segitiga Emas Kabupaten Sumenep.

3. Inovasi tema wisata di destinasi Pulau Segitiga Emas Kabupaten Sumenep.

Variabel-variabel baru di atas akan dimasukkan ke dalam Analisis Delphi Tahap II atau tahap iterasi (pengulangan) I sebagai variabel tambahan. Hal ini dilakukan dengan cara ditanyakan kembali melalui in-dept interview atau wawancara tertutup kepada responden penelitian.

\section{B. Eksplorasi Analisis Delphi Tahap II (Iterasi 1)}

Pada analisis delphi tahap II yang merupakan tahap tahap iterasi atau pengulangan, dilakukan dengan eksplorasi pendapat responden terhadap variabel yang belum tercapai kesepakatan antar responden pada analisis delphi tahap I sebelumnya serta variabel tambahan apabila terdapat penambahan variabel baru diajukan oleh para responden untuk dijadikan faktor baru dengan cara melakukan wawancara dan konfirmasi kepada responden yang sama.

Tabel 2.

Hasil Eksplorasi Analisis Delphi Tahap II

\begin{tabular}{|c|c|c|}
\hline $\begin{array}{c}\text { Hasil Analisis } \\
\text { (Konsensus } \\
\text { Responden) }\end{array}$ & $\begin{array}{l}\sum \text { (Jumlah } \\
\text { Variabel) }\end{array}$ & Variabel \\
\hline $100 \%$ & 7 & $\begin{array}{l}\text { kedekatan antar destinasi wisata; } \\
\text { perbedaan rute keberangkatan dan } \\
\text { kepulangan; rute alternatif } \\
\text { penyebrangan; ketersediaan kelompok } \\
\text { penyedia jasa penyebrangan; kerjasama } \\
\text { antara pengelola dan agent travel; modal } \\
\text { sosial masyarakat di kawasan } \\
\text { wisata;inovasi tema wisata }\end{array}$ \\
\hline $83 \%$ & 1 & $\begin{array}{l}\text { tersedianya signal internet di kawasan } \\
\text { wisata }\end{array}$ \\
\hline $177 \%$ & 1 & $\begin{array}{l}\text { kantor informasi wisata di kawasan } \\
\text { wisata }\end{array}$ \\
\hline
\end{tabular}

Total Variabel

9

Berdasarkan Tabel 3 hasil analisis delphi tahap II dapat diketahui bahwa terdapat 7 variabel yang 100\% responden sepakat dapat mempengaruhi integrasi pengembangan kawasan wisata di Pulau Segitiga emas, Kabupaten Sumenep, dan 1 variabel yang disepakati 83\% mempengaruhi integrasi pengembangan kawasan wisata di Pulau Segitiga Emas Kabupaten Sumenep, serta 1 variabel yang disepakati oleh $17 \%$ responden dapat mempengaruhi integrasi pengembangan kawasan wisata di Pulau Segitiga Emas Kabupaten Sumenep.

Hasil Analisis Delphi Tahap II

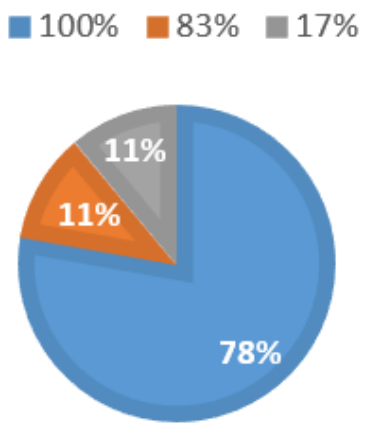

Gambar 2. Diagram hasil analisis delphi tahap II

Berdasarkan Gambar 2 dapat diketahui analisis dephi tahap II sebesar $78 \%$ responden setuju $100 \%$ terhadap variabel yang mempengaruhi integrasi pengembangan kawasan wisata di Pulau Segitiga Emas Kabupaten Sumenep. Terdapat 7 variabel disepakati oleh responden sebagai faktor-faktor yang mempengaruhi integrasi pengembangan kawasan wisata di Pulau Segitiga Emas Kabupaten Sumenep. Dari jumlah total 9 variabel pada analisis delphi tahap II ini, terdapat 2 variabel yang belum disepakati $100 \%$ oleh responden. Dua variabel atau faktor yang belum mencapai konsensus diantaranya, yaitu ketersediaan kantor informasi wisata dan tersedianya signal internet di kawasan wisata.

\section{Eksplorasi Analisis Delphi Tahap III (Iterasi 2)}

Analisis Delphi Tahap III merupakan tahap iterasi ke 2 dengan kembali atau mengulang dalam melakukan eksplorasi pendapat responden terhadap variabel yang belum mencapai konsensus atau kesepakatan pada tahap sebelumnya yaitu analisis delphi tahap II atau iterasi ke 1. Hasil analisis delphi tahap II dari para responden yang akan dikonfirmasikan kembali pada analisis delphi tahap III dengan melakukan wawanacara (in-dept-interview) kepada responden yang sama.

Tabel 4.

Hasil Eksplorasi Analisis Delphi Tahap III

\begin{tabular}{ccl}
\hline \hline $\begin{array}{c}\text { Hasil Analisis } \\
\text { (Konsensus } \\
\text { Responden) }\end{array}$ & $\begin{array}{c}\sum \text { (Jumlah } \\
\text { Variabel) }\end{array}$ & \multicolumn{1}{c}{ Variabel } \\
\hline $100 \%$ & 1 & $\begin{array}{l}\text { tersedianya signal internet di kawasan } \\
\text { wisata } \\
\text { kantor informasi wisata di kawasan } \\
\text { wisata }\end{array}$ \\
Total Variabel & 1 & \\
\hline \hline
\end{tabular}

Berdasarkan tabel hasil analisis delphi tahap III tersebut didapatkan semua variabel sudah konsensus dan disepakati. Dimana terdapat 1 variabel yang 100\% disepakati oleh responden dapat mempengaruhi integrasi pengembangan kawasan wisata di Pulau Segitiga emas, Kabupaten Sumenep yaitu variabel tersedianya signal internet di kawasan wisata. Sedangkan, 1 variabel lagi yaitu ketersediaan kantor informasi wisata di kawasan wisata disepakati tidak mempengaruhi integrasi pengembangan kawasan wisata di Pulau Segitiga emas (Gili Iyang, Gili Labak, dan Gili Genting), Kabupaten Sumenep. Untuk lebih jelasnya, berikut 
gambar diagram ilustrasi dari hasi1 eksplorasi analisis delphi tahap III.

\section{Hasil Analisis Delphi Tahap III}

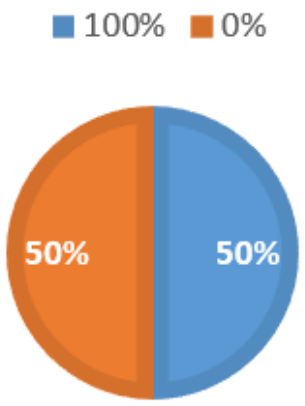

Gambar 3. Diagram hasil analisis delphi tahap III

Berdasarkan Gambar 3 analisis delphi tahap III sebesar $50 \%$ responden setuju $100 \%$ terhadap variabel yang mempengaruhi integrasi pengembangan kawasan wisata di Pulau Segitiga Emas Kabupaten Sumenep yaitu tersedianya signal internet di kawasan wisata. Dan sebesar 50\% responden tidak setuju atau setuju $0 \%$ terhadap variabel ketersediaan kantor informasi wisata. Setuju 100\% terhadap variabel tersedianya signal internet di kawasan wisata mempengaruhi integrasi pengembangan kawasan wisata di Pulau Segitiga Emas Kabupaten Sumenep, salah satu alasan wisatawan untuk berkunjung ke tempat wisata dan esensi berwisata sudah berubah dimana jaman sekarang berwisata sebagai ajang pamer di media sosial sehingga dibutuhkan signal internet di kawasan wisata.

Sedangkan, variabel ketersediaan kantor informasi wisata (TIC) di kawasan wisata disepakati tidak mempengaruhi integrasi pengembangan kawasan wisata di Pulau Segitiga Emas Kabupaten Sumenep karena selama ini menggunakan media online sebagai penyebar informasi wisata di masingmasing pulau yang termasuk ke dalam Pulau Segitiga Emas Kabupaten Sumenep.

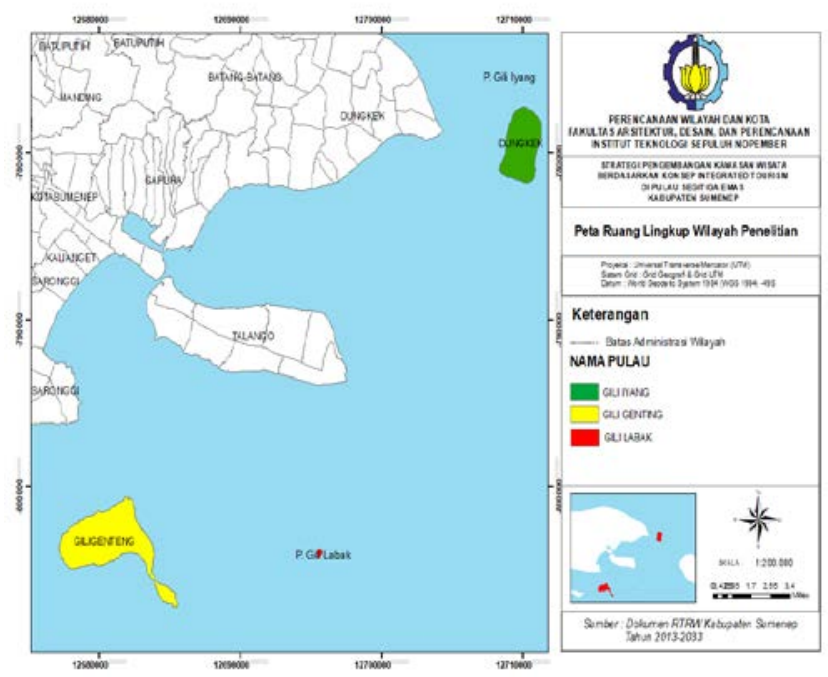

Gambar 4. Peta Wilayah Penelitian Pulau Segitiga Emas Kabupaten Sumenep

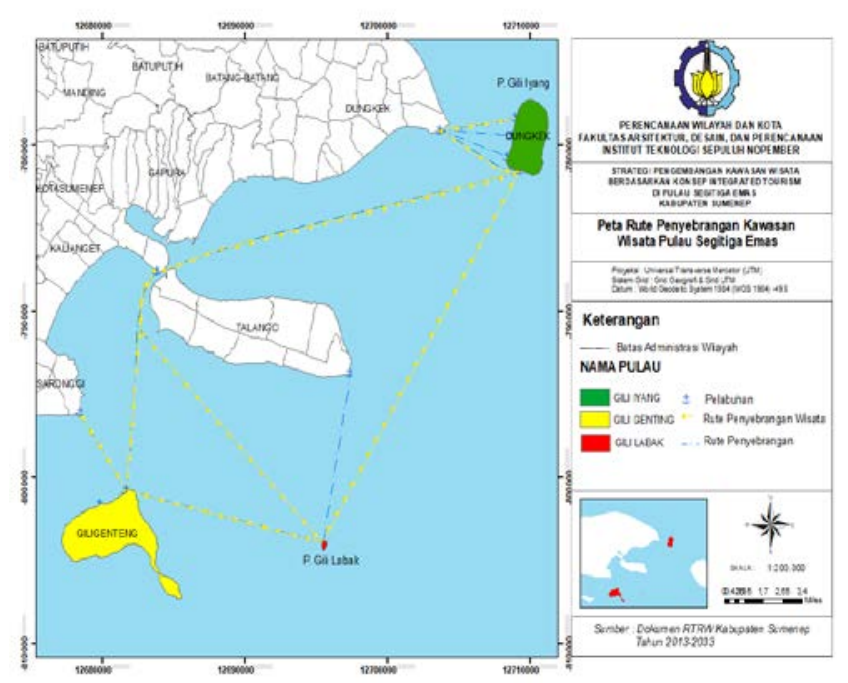

Gambar 5. Peta Rute Penyebrangan di Kawasan Wisata Pulau Segitiga Emas Kabupaten Sumenep

\section{KESIMPULAN}

Penggunaan variabel pada analisis delphi sebelumnya berjumlah 25 variabel. Setelah dilakukan tahapan analisis delphi, jumlah variaebl bertambah menjadi 28 variabel. Hal ini karena terjadi penambahan faktor yang dijadikan sebagai variabel baru sebanyak 3 variabel berdasarkan usulan dari responden. Sehingga jumlah keseluruhan variabel pada Analisis Delphi penelitian ini yaitu 28 variabel. Kemudian, berdasarkan hasil akhir analisis delphi yang telah dilakukan sampai dengan tahap III analisis delphi sebanyak 27 variabel mempengaruhi integrasi pengembangan kawasan wisata di Pulau Segitiga Emas Kabupaten Sumenep. Sedangkan, 1 variabel tidak mempengaruhi integrasi pengembangan kawasan wisata di Pulau Segitiga Emas Kabupaten Sumenep. Jadi berdasarkan penjelasan tersebut, didapat faktor-faktor yang mempengaruhi integrasi pengembangan kawasan wisata di Pulau Segitiga Emas Kabupaten Sumenep.

Faktor daya tarik wisata dipengaruhi oleh kedekatan antar destinasi wisata, diferensiasi atraksi wisata alami, dan diferensiasi event.

Faktor aksessibilitas dipengaruhi oleh jenis fasilitas penyebrangan, jadwal penyebrangan, kualitas moda transportasi penyebrangan, kemudahan memperoleh moda transportasi penyebrangan, kemudahan mendapatkan informasi jadwal penyebrangan, biaya moda transportasi penyebrangan, ketersediaan rute penyebrangan, perbedaan rute keberangkatan dan kepulangan, dan adanya rute alternatif penyebrangan.

Faktor fasilitas pendukung dipengaruhi oleh ketersediaan kelompok penyedia jasa penyebrangan, keterpaduan fasilitas penginapan, keterpaduan fasilitas tempat makan, keterpaduan infrastruktur, dan adanya signal internet/jaringan telekomunikasi.

Faktor kelembagaan dipengaruhi oleh peran dan upaya pemerintah, modal sosial masyarakat lokal, keterlibatan masyarakat dalam pengelolaan, keterlibatan masyarakat dalam pemasaran dan perencanaan, kerja sama antara pemerintah, pengelola, investor dan masyarakat lokal, serta kerja sama antara pengelola dan agen travel.

Faktor promosi dipengaruhi oleh publikasi potensi wisata, pemasaran wisata, dan inovasi tema wisata.

Dari penjelasan di atas dapat diketahui bahwa terdapat 27 faktor yang mempengaruhi integrasi pengembangan kawasan 
wisata di Pulau Segitiga Emas Kabupaten Sumenep. Dan dapat disimpulkan bahwa hanya 1 faktor yang tidak mempengaruhi integrasi pengembangan kawasan wisata di Pulau Segitiga Emas Kabupaten Sumenep. Faktor tersebut yaitu ketersediaan kantor informasi wisata (TIC) di kawasan wisata. Hal ini karena para stakeholder sepakat bahwa saat ini belum diperlukan kantor informasi wisata (TIC) untuk dilakukan integrasi pengembangan kawasan wisata di Pulau Segitiga Emas, para stakeholder sepakat dengan memilih untuk mengoptimalkan dan memaksimalkan media online dan website resmi sebagai sarana informasi dan promosi wisata Pulau Segitiga Emas Kabupaten Sumenep dengan kerjasama antara pemerintah, agent travel, dan pengelola wisata maka informasi dapat tersalurkan kepada wisatawan dan masyarakat umum.

\section{DAFTAR PUSTAKA}

[1] PERDA RPJPD (Rencana Pembangunan Jangka Panjang Daerah) Kabupaten Sumenep Th 2009-2029. .

[2] N. Muhadjir, Metodologi penelitian kualitatif: pendekatan positivistik, rasionalistik, phenomenologik, dan realisme metaphisik telaah studi teks dan penelitian agama. Yogyakarta: Rake Sarasin, 2004.

[3] S. Sugiyono, Metode Penelitian Kuantitatif, Kualitatif, dan R\&D. Bandung: AFABETA, 2011.

[4] H. A. Linstone, M. Turoff, and O. Helmer, The Delphi Method Techniques and Applications Edited by. New Jersey: New Jersey Institute of Technology. 